\title{
Is French science in decline...
}

...or have its failings been greatly exaggerated? Declan Butler finds out.

S regarder le nombril - navel gazing - is a national sport in France, and that gaze has turned to science. The sentiment that French research is in steep decline has become a recurrent theme of political discourse, newspaper editorials and TV talk shows.

France's research system has its problems — from unwieldy bureaucracies to dilapidated universities. As a result, many gaze across the channel, and the Atlantic, to the Anglo-Saxon system as a model for science and innovation.

Key science indicators reveal a more complex picture, however. Despite deep funding cuts, basic research in France seems to be stable in terms of overall output of papers, but is losing ground in 'visibility' - the papers that have the greatest impact. The country does have a chronic weakness in private-sector research, though it is hardly alone in this malaise.

The challenge for French research in which politicians can make the biggest difference is the decline in government spending. Recent history reveals an 'accordion' effect in which right-leaning governments squeeze research funding, and socialist ones expand it (see graphic).

President François Mitterrand's election in 1981 marked the start of a golden decade for French research as spending grew rapidly under successive socialist governments. But the growth came to an abrupt end in 1993 when conservatives were elected under Prime Minister Edouard Balladur. And spending has fallen further since Jacques Chirac was elected as president in 1995 , albeit punctuated by a rise under socialist prime minister Lionel Jospin from 1997 to 2002. But the net result of Chirac's 12-year presidency is that spending on science was lower as a proportion of GDP in 2005 - 2.13\% - than it was in 1985.

This decline runs contrary to the goal of raising average science spending from $2 \%$ to $3 \%$ of GDP by 2010 , which EU governments agreed in Lisbon in 2000. Some smaller European nations have already reached this target, although they remain the exceptions. Britain and Germany are the two European countries most directly comparable to France in research power, and the three together account for twothirds of all research in the European Union. So how does France compare to them?

Germany overtook France as Europe's larg-

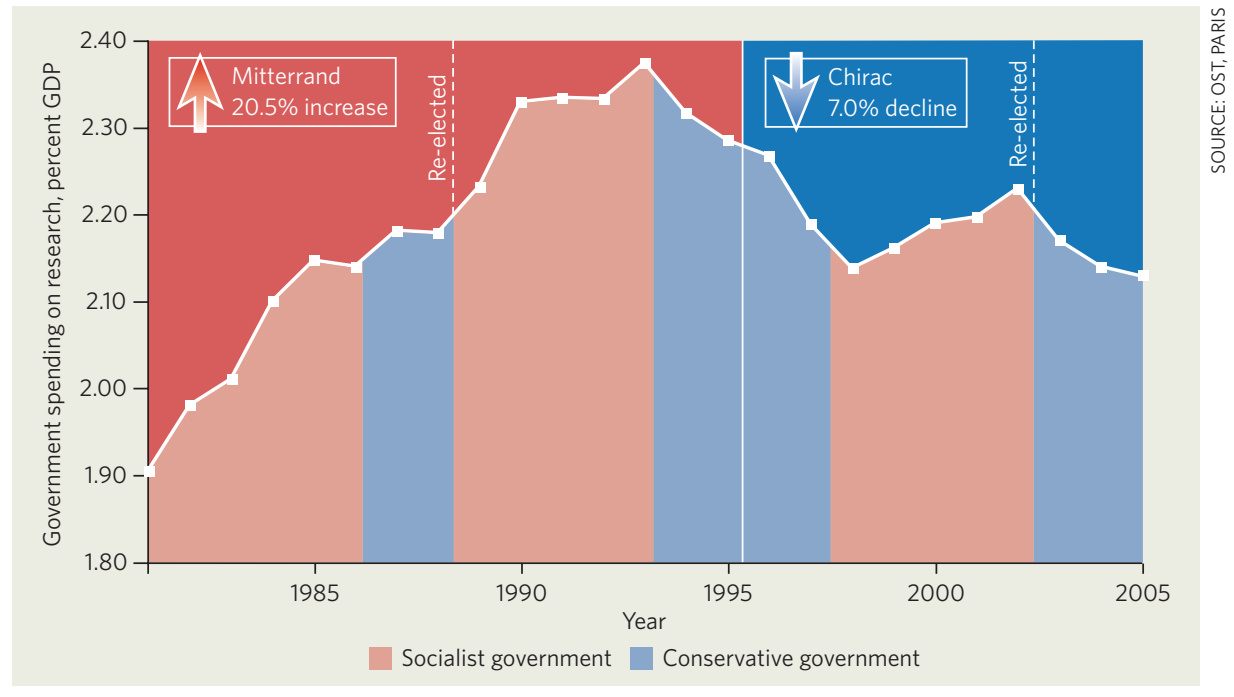

est research spender in 1997, and its budget reached $2.52 \%$ of GDP in 2003. In the decade $1993-2003$, UK spending fell by $8.7 \%$ to $1.88 \%$ - a similar drop to that seen in France.

But France has done better than Britain in private sector funding. Between 1993 and 2003, industry funding grew by $8 \%$ - close to Germany's $9 \%$. By contrast, Britain has seen a $15 \%$ drop over this period - by 2003 , to just $44 \%$ of its total science spending, well below the EU average of $54 \%$. At $51 \%$, France is very much an average European player and still falls short of Japan, where industry accounts for three-quarters of research funding, and the United States and Germany, where it accounts for two-thirds.

How does all this spending translate into research outputs? France's share of the world's scientific papers had reached $5.4 \%$ by 1999 , but by 2004 it had dropped to $4.7 \%$, at which point it was displaced from fifth place in the world league by China. A comparable drop has occurred in most European countries, including Germany and Britain, and in the United States. "This negative rate is directly related to a positive growth rate in several countries, especially China," says Henk Moed, an expert in science indicators at Leiden University in the Netherlands.

The downward trends in research outputs is most marked in France's share of patents, particularly in the important US market. France's share of US patents dropped by $14 \%$ between
1999 and 2004 to $2.5 \%$, whereas the EU's share as a whole fell by just $2 \%$ over this period to $17.1 \%$. As with scientific publications, part of this drop is down to emerging economies in Asia. North America's share of US patents fell by $3 \%$ to $49.9 \%$ during this time; Asias share rose by $6 \%$ to reach $30.1 \%$, and South Korea overtook France and Britain with $2.6 \%$ of all US patents.

Of all the indicators, few can hurt French pride more than having so few institutions in the top rankings of international universities. But the poor performance of French universities is perhaps also exaggerated.

Under France's complex system, most labs belong to one or more research organizations and a university, but automated indicators such as Thomson's Essential Science Indicators count only the first affiliation in an author address, which means that French institutions are often not attributed correctly. To tackle this disparity, Thomson started a project in February with the Paris-based Observatoire des Sciences et des Techniques (OST) to get a truer picture of French science.

So the figures, although no cause for complacency, are not as bleak as some of the rhetoric might suggest. "We shouldn't overdramatize the supposed decline," says Ghislaine Filliatreau, director of the OST, "French basic science is still holding its own, despite poor funding, but risks being outspent and outperformed by other countries."

Declan Butler is a senior reporter for Nature, based in Paris. 


\section{Crop biodiversity project receives seed money}

Funding has been secured for a major biodiversity project that could help safeguard seeds and genetic data for up to 165,000 varieties of 21 food crops.

The project, carried out by the Global Crop Diversity Trust and the United Nations Foundation, will replenish stores of seeds in poorly maintained seed banks throughout the world and ensure that backup stocks are established. It will also create a database that gives plant breeders access to the genetic blueprints underlying the different strains.

Designed to ensure that plant breeders retain as much flexibility as possible in creating improved crop strains, the project will be paid for by a $\$ 30$-million grant from the Bill \& Melinda Gates Foundation and $\$ 7.5$ million from the government of Norway.

\section{India puts Italian AGILE satellite into orbit}

Italy's satellite AGILE was launched by India's PSLV rocket on 23 April, in India's first commercial launch solely for a foreign spacecraft.

AGILE, which had been delayed for two years as Italy's space leaders debated the launch, will provide the first measurements of high-energy gamma rays since NASA's Compton Gamma-Ray Observatory fell back to Earth in 2000. A NASA programme called GLAST will make similar measurements following its launch later this year.

The PSLV is due to launch India's first spacecraft mission to the Moon, Chandrayaan-1, in 2008.

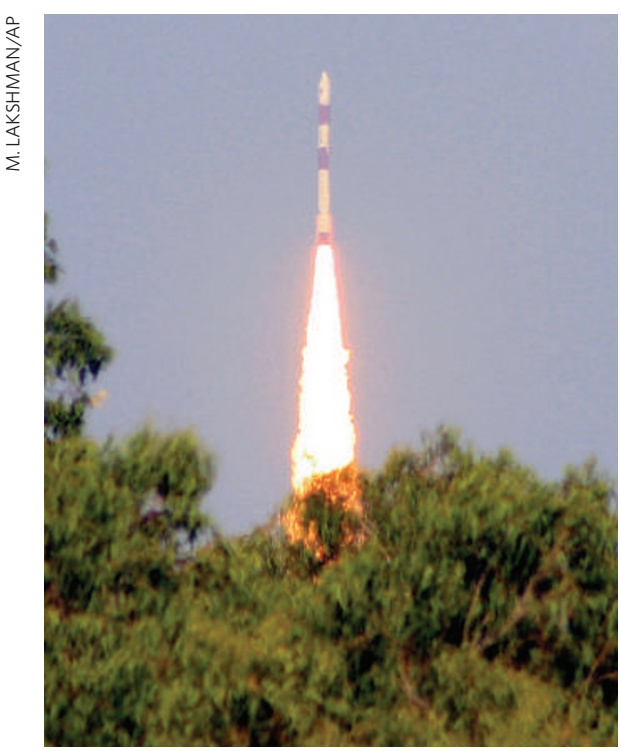

AGILE manoeuvre: India's PSLV rocket takes off.

\section{Cassini offers solution to the riddle of the rings}

Fresh light has been shed on why William Herschel was able to sketch the rings around Uranus in the late eighteenth century (inset). Other astronomers were unable to confirm his sighting with more powerful telescopes until the Keck telescope on Hawaii confirmed the rings' existence in 1977 (right).

Stuart Eves of Surrey Satellite Technology, a UK satellite company, told the Royal

Astronomical Society's National Astronomy Meeting in Preston that the Cassini mission has shown that Saturn's rings are darkening and expanding. If the same phenomenon occurred around Uranus, he says, that would explain why its rings have become progressively harder to see. Herschel's sketch shows the rings in the right orientation, and his description that they are reddish has also been confirmed.

\section{Contaminated-blood inquiry begins in Britain}

An independent public inquiry has started in Manchester, UK, into how thousands of haemophiliacs were infected with HIV and hepatitis $C$ in the 1970s and 1980s by being given contaminated blood products. It follows related scandals in France, Japan, Germany and the United States, where similar proportions of haemophiliacs were infected.

The inquiry, led by Labour peer Peter Archer, will examine the timetable of decisions to introduce heat-inactivated clotting factors and products from the United States that were known to be highrisk because of the US practice of paying donors. The focus of HIV infection will be the narrow window between the discovery of the virus as the cause of AIDS in 1983 and the introduction of safe blood products in 1985. Haemophiliacs have long demanded an inquiry, which could open the way for compensation.

\section{Germany relaxes rules on postdoc contracts}

A controversial rule disallowing scientists in Germany from working on short-term contracts for longer than 12 years - or 15 years in the case of clinical research - has been retracted.

The rule was introduced in 2001 as part of a package of measures intended to improve the lot of young German researchers by limiting the duration of insecure postdoc work (see Nature 415, 257-258; 2002). But it was criticized from the beginning for introducing unnecessary restrictions - and for discriminating against women, who are

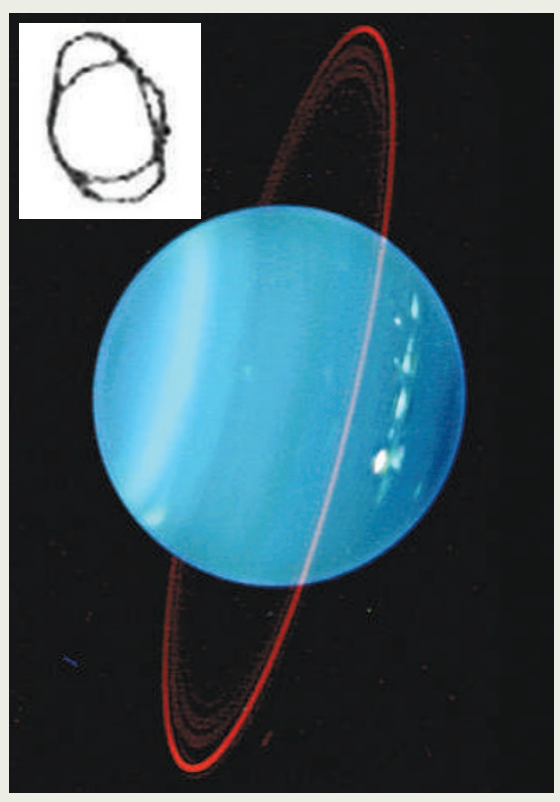

likely to take time off to start a family during their 20s and 30s.

A replacement law that allows grant money to be used to pay postdoctoral researchers without time restriction came into force last week.

\section{Canada launches open- access medical journal}

An open-access medical journal has been set up by editors who left Canada's bestknown medical publication, the Canadian Medical Association Journal (CMAJ), last year in a disagreement over its editorial independence.

The journal, Open Medicine, will be published by a non-profit organization and will not accept advertising from makers of drugs or medical devices. It plans to sustain itself mostly by voluntary contributions for the first year and then start charging authors to publish.

"We are launching Open Medicine as an open-access journal because we believe the current, closed-access model is inconsistent with the values of medicine," says co-editor Anita Palepu. Palepu, seven colleagues and 16 board members left the CMAJ after two of its editors were dismissed for publishing a politically sensitive news story in the journal.

\section{Correction}

In our News Feature "Is French science in decline..." (Nature 446, 854; 2007), the axis on the graph should have read: "Gross domestic expenditure on R\&D as a percentage of GDP". And the sentence "The challenge for French research in which politicians can make the biggest difference is the decline in government spending" should have referred to 'science' not 'government' spending. 